\title{
Risk factors control in female patients treated with primary percutaneous coronary intervention
}

\author{
Dragana Bačić ${ }^{1}$, Jelena Rakočević2, Vojislav Giga ${ }^{1,3}$, Jelena Stepanović ${ }^{1,3}$, Ivana Paunović ${ }^{1}$, \\ Branko Beleslin ${ }^{1,3}$, Ana Đorđević-Dikić ${ }^{1,3}$ \\ ${ }^{1}$ Cardiology Clinic, Clinical Center of Serbia, Belgrade, Serbia, ${ }^{2}$ Institute of Histology and Embryology, University of \\ Belgrade, School of Medicine, Serbia, ${ }^{3}$ School of Medicine, University of Belgrade, Belgrade, Serbia
}

Abstract Introduction. The risk of heart disease in women has been underestimated in the past due to the misperception that females are 'protected' against cardiovascular diseases (CVD). Also, there are some data that risk factors are poorly regulated in female patients after myocardial infarction (MI). The aim of our study was to examine coronary risk factors control in female patients treated with primary percutaneous coronary intervention after MI.

Methods. Our study included 59 consecutive female (mean age $58.53 \pm 8.74$ ) patients treated with primary PCI for ST segment elevation MI. After two years of index event all the patients had laboratory analysis of lipid parameters, with optimal control defined as LDL-cholesterol $<1,8 \mathrm{mmol} / \mathrm{L}$. Optimal blood pressure was defined as BP $<130 / 80 \mathrm{mmHg}$. Also smoking status was assessed in all patients, as well as physical activity (at least $30 \mathrm{~min}$ of exercise on 5 or more days/week). Risk factors awareness was also assessed.

Results. Our data show that majority of female patients had poorly regulated risk factors two years after ST segment elevation MI. Non-optimal blood pressure was present in $86 \%$ and LDL cholesterol was above $1.8 \mathrm{mmol} / \mathrm{I}$ in $45 \%$ of patients. More than a half of patients $(54.2 \%)$ continued to smoke. Sedentary lifestyle was dominant in our group of patients ( $52.5 \%$ didn't have any physical activity).Vast majority of patients (82.8\%) did not change their nutrition habits, and that percentage was significantly higher in female patients with $B M I>25$ than in patients with $B M I<25(p=0.003)$, whereas changes in nutritional habits were not related to educational status ( $p=N S$, high vs. other education). Majority of patients $68 \%$ considered to have optimally regulated risk factors.

Conclusion. Our data show that vast majority of female patients had poorly regulated risk factors for coronary artery disease after ST segment elevation myocardial infarction, with low awareness of risk factors levels.

Key words risk factors, females, primary percutaneous coronary intervention

\section{Introduction}

ardiovascular diseases (CVD) are the leading cause of mortality, disability and loss of work ability, also causing high costs of health care, particularly in countries with a high percentage of elderly population. A recent report of EuroHart shows that women are less likely involved in cardiovascular research, while their clinical manifestations of CVD develop 7 - 10 years later than in men. It was observed that the prevalence of myocardial infarction increased among middle aged women ( 35 - 54 years old) in the last two decades, while the increase was observed in the men same age ${ }^{1}$.

Besides the significant progress in the treatment of cardiovascular diseases, the number of younger women who suffer from myocardial infarction is increasing ${ }^{2,3}$. It is estimated that in Europe about $55 \%$ of causes of death in women are cardiovascular etiology, especially coronary artery disease and stroke. Although it is considered that cardiovascular disease occurs less frequently in women due to protective effects of estrogen, it is often forgotten that contraceptive pills, smoking, obesity and sedentary lifestyle increases this risk.

After menopause the blood pressure and cholesterol levels increase in middle aged women, as the stroke which doubles its risk ${ }^{4}$. The question remains whether estrogen status plays a role in delaying atherosclerosis in women ${ }^{5}$. It is known that women with early menopause have a shorter life span compared with women whose menopause starts in expected years or it is delayed ${ }^{6}$. It is believed that estrogens exert their protective cardiovascular effect affecting different metabolic factors, increasing HDL-cholesterol and reducing LDL-cholesterol levels, as well as markers of inflammation and blood coagulation? 
Usually lower socio-economic status in women has pronounced negative influence on healthy lifestyle, obesity and other risk factors for CVD compared to men. Combination of work and stress around the household is also considered one of the triggers for the increased CVS risk in women. ${ }^{8}$

Nine potentially modifiable risk factors (smoking, hypertension, diabetes, hip-waist ratio, diet, physical activity, alcohol consumption, lipids, and psychosocial factors) are calculated as $94 \%$ of cardiovascular risk factors in women. For young women with a satisfactory level of 5 risk factors (smoking, hypertension, diabetes, cholesterol and BMI), ischemic heart disease and cardiovascular disease are events that occur rarely. Unfortunately only $20 \%$ of women younger than 40 years are familiar with these risk factors, and $48 \%$ of women have two or more clustered metabolic risk factors for CVD.

Secondary prevention of cardiovascular disease represents a set of measures that are available to individuals and entire population in order to detect diseases faster with more successful treatment, or measures taken against the recurrence or progression of disease in patients who already have cardiovascular disease. Modification of risk factors is a key part of secondary prevention of coronary artery disease.

Secondary prevention measures of cardiovascular disease include control of blood pressure, smoking cessation, achieving target blood lipid levels, increasing physical activity, achieving the target values of body weight, monitoring and normalization of glycaemia level, with an adequate therapy of existing diseases (antiplatelet/anticoagulant therapy, ACE inhibitors, beta-blockers and statins).

The aim of our study was to investigate whether women after acute myocardial infarction treated with primary percutaneous intervention adhere to measures of secondary prevention of cardiovascular diseases, to observe the presence of CVD risk factors and their awareness of prevention necessity and treatment of existing coronary heart disease.

\section{Methods}

Our research included women with acute myocardial infarction with ST-segment elevation (STEMI) undergoing primary percutaneous intervention during the period of 2010 - 2011 at the Clinical Center of Serbia.

Follow-up was performed two years after STEMI (visit to doctor or by telephone interview) when patients' data were obtained concering risk factors, treatments and regular medical controls. It was recorded the occurence of following risk factors: hypertension, diabetes mellitus, menopause, levels of blood lipids (total cholesterol, LDL-cholesterol, HDL-cholesterol, triglycerides), CVD heredity and smoking. Presence of CVD symptoms was also recorded (shortness of breath, fatigue, chest pain and palpitations) and patients health habits (diet, regular medical check-ups, regular intake of prescribed therapy and information about their own disease).

For the statistical analysis methods of descriptive statistics were used, while $\chi 2$-test was used for the com- parison of categorical variables. Statistical significance was set at $p<0.05$.

\section{Results}

The study included 59 women with acute myocardial infarction treated with primary percutaneous intervention, average age $58.5 \pm 8.74$ years. Most of the patients had completed secondary school $(n=39,66.1 \%)$, while a smaller number had high $(n=9,15.3 \%)$ and higher level of education ( $n=7,11.9 \%$ ), while only 4 patients $(4,8 \%)$ finished only primary school.

\section{Analysis of cardiovascular risk factors}

A total of 14 patients (23.7\%) had diabetes mellitus (DM), the majority $(10,66.7 \%)$ used oral antidiabetic agents, four patients (4.1\%) were using insulin, while one patient regulated glycaemia exclusively by dietary regime. Average blood glucose levels did not show statistically significant difference between the groups of patients who used oral hypoglycemic therapy or insulin $(p=0.336)$.

Most women $(51,86.4 \%)$ stated that they have elevated levels of blood pressure, almost half $(45$, or $45.9 \%)$ had hyperlipidemia. In the study population there were no active smokers, while 32 of them (54.2\%) were former smokers. Family history of cardiovascular disease was noted in 40 women (67.8\%).

Even 46 respondents (78\%) were in menopause at the time of the coronary event, while the average time from the start of menopause to the occurrence of acute myocardial infarction was 11.5 years (IQR 3 - 17). The number of registered risk factors did not differ significantly between patients who were in menopause and those who did not $(p=0.959)$.

Analysis of the frequency risk factors between the two groups of respondents showed that there was only there difference in the occurrence of DM. Thus, diabetes mellitus was more frequently registered in women who had been menopausal upon the occurrence of acute myocardial infarction compared to women who were in menopause $(p<0.05)$. The differences in other risk factors are not registered.

\section{Analysis of health problems}

A total of 28 respondents (47.5\%) stated having some cardiovascular health problems. Ten of them (12.8\%) reported dyspnea, 9 (11.5\%) chest pain, $9(11.5 \%)$ had fatigue, while only one patient (1.3\%) reported palpitations. Three patients (3.8\%) were had other health problems. It was observed that patients who reported health problems were significantly older than the group of women with no symptoms (mean age 64.4 vs. 58.3 years, $p<0.005)$.

\section{Analysis of health habits}

Most patients reported to adhere to the instructions about diet (82.8\%), to go to regular cardiologist controls $(87.9 \%)$ and regularly take prescribed medication 


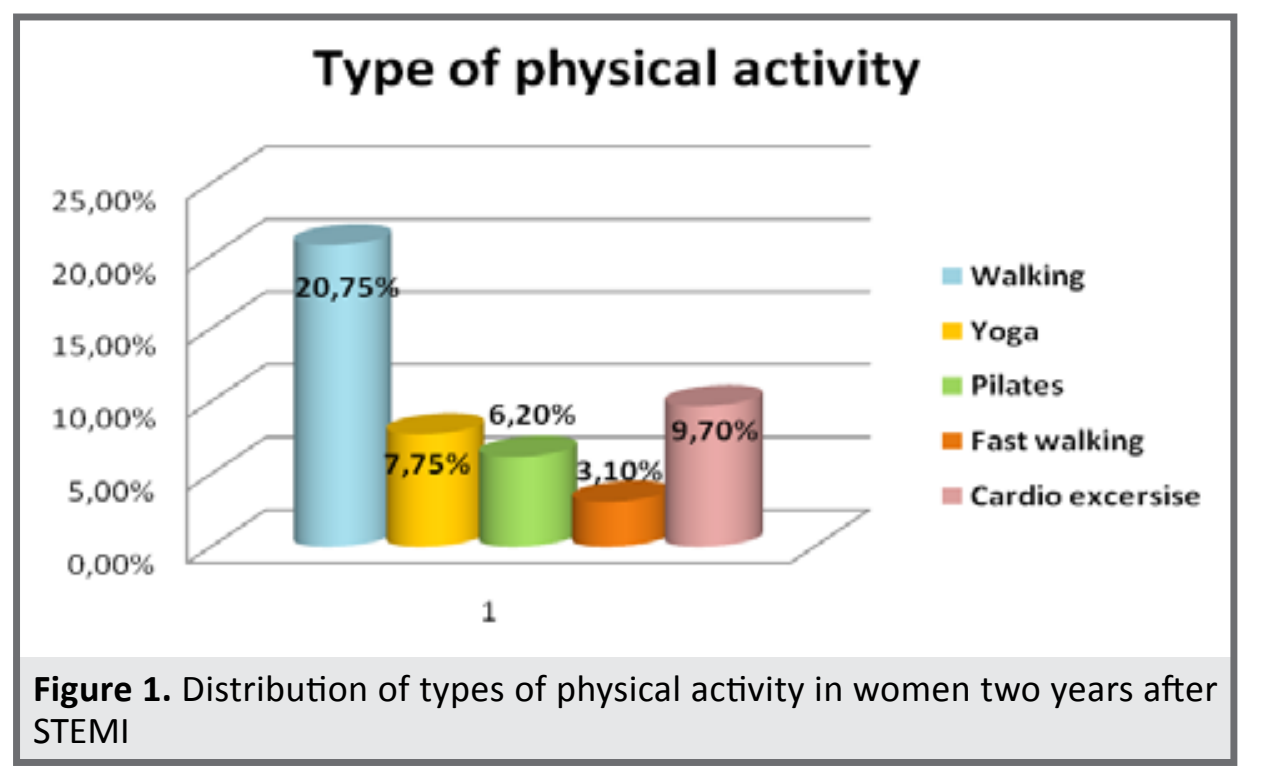

(96.6\%). Just over half of women (57.6\%) thought to be well informed about their disease.

In the group of patients with diabetes mellitus ( $\mathrm{n}=$ 14), 12 of them adhere to the instructions about diet, go for regular check-ups with cardiologist and regularly takes therapy. However, half of these patients ( 7 of them) believed that it was not sufficiently informed about their disease as a risk factor for coronary disease.

The subjects with the highest level of education were more informed about their disease than women with lower level of education $(p=0.002)$. There was no statistically significant difference when comparing regular cardiology controls between the two groups.

Almost half $(47 \%, n=28)$ of patients was not engaged in physical activity after myocardial infarction, while the frequency of different physical activities in the other group shown on Figure 1.

\section{Discussion}

The results of our study showed that the majority of patients two years after myocardial infarction still had uncontrolled levels of blood pressure, increased levels of blood lipids and body weight, with sedentary lifestyle. On the other hand, most of these patients believe that they are well informed about their disease.

Our results agree with the World Health Organization statement that there is a lack of awareness among women that cardiovascular diseases are a major threat to their health status ${ }^{9}$. This fact is reflected in the attitude of many young women who are considered to have a higher risk of tumors than from cardiovascular disease.

It is known that the cardiovascular mortality is higher in younger women than in men the same age. However the consequences of stroke are much more serious in women than in men. Also in women with diabetes mellitus, cardiovascular mortality rate is higher. Possible reason for this it the fact that women are less informed women about the seriousness of cardiovascular events?.

When it comes to sex difference in the risk of ischemic heart disease, there were three paradoxes. First, women have angina pectoris more frequently than men, but with lower prevalence of obstructive coronary atherosclerosis and heart disease. Second, although the number of women suffering from CVD is increasing, coronary angiography showed that women with symptomatic disease have much better prognosis than men. Third, the overall CVD prognosis is worse in women compared to men ${ }^{10}$.

These results indicate a specific sex differences in the pathophysiology of ischemic heart disease. In women, angina pectoris often presents as a result of existing microvascular disease, while ischemic heart disease in men is often caused by obstructive coronary disease.

According to the 2012 European recommendations for the prevention of cardiovascular diseases control of modifiable risk factors (hypertension, hypercholesterolemia, smoking, physical inactivity and obesity) is includ$\mathrm{ed}^{11}$. However it seems that the smaller accent was given on educating women who are in menopause and who have associated risk factors. It is necessary to pay special attention to the primary prevention of this group of women, with timely preventing the occurrence of cardiovascular events. Women entering menopause are subjected to greater CVD risk, which increases when associated risk factors are present. Our study has corroborated with this fact in the two-year follow-up of patients, whose cardiovascular risk increased more because they had associated cardiovascular risks.

Most of those present risk factors were modifiable, with poorly regulated levels of blood pressure (systolic and diastolic) in as many as $86 \%$ of cases. Mason PJ et al. in WACS study concluded that systolic blood pressure was a strong and independent predictor of cardiovascular events in women of middle and older age with already diagnosed coronary heart disease, and also an independent risk factor for cardiovascular morbidity and mortality in primary and secondary prevention. ${ }^{12}$

It is known that higher levels cholesterol contribute to atherosclerosis, which further increases the risk of myocardial infarction and stroke ${ }^{13}$. However despite regular medical controls in $45 \%$ of our patients inadequately regulated levels of LDL-cholesterol were registered.

Dosed physical activity with moderate to intense workout $\geq 3$ times a week for 30 minutes is advised after 
myocardial infarction. However our two-year follow-up showed that the sedentary lifestyle is dominant in over $50 \%$ of cases. Even $82.8 \%$ did not change eating habits, especially patients with $\mathrm{BMI}>25 \mathrm{~kg} / \mathrm{m}^{2}$.

The question is whether promoters of health and other population health workers, besides doctors should be included in better education of women with $\mathrm{CV}$ risk factors and their modification, with raising awareness about the importance of lifestyle changes. According to the European recommendations for the prevention of CVD in clinical practice in patients with coronary artery disease, it is necessary to achieve a more rigorous risk factor control.

The prevention program states that they should be integrated into everyday life activities. It is important that nurses engaged in the promotion of health should also be well integrated into the health care system, to influence modification of health habits among women who have had a coronary event, and where risk of new cardiovascular events still exists.

Despite all the efforts in the implementation of preventive measures, the number of women who suffer from CVD is not reduced. The question of whether opening of a counseling center for women would help in better prevention at all three levels of prevention, as well as the involvement of all health workers and the whole community in the implementation of appropriate measures. That way large number of participants in health promotion and the women would be adequately informed about the risk factors and preventive measures, so that their adverse impact could be reduced.

However, despite all these indicators, our study population showed that $68 \%$ of patients considered having optimally controlled risk factors.

\section{Conclusion}

Our data show that vast majority of female patients had poorly regulated risk factors for coronary artery disease after ST segment elevation myocardial infarction, with low awareness of risk factors levels.

\section{References}

1. Towfighi A, Zheng L, Ovbiagele B. Sex-specific trends in midlife coronary heart disease risk and prevalence. Arch Intern Med 2009;169:1762 - 1766 .

2. European Cardiovascular Disease Statistics, 2012 edition. Authors, Melanie Nichols, Nick Townsend, Peter Scarborough and Mike Rayner, British Heart Foundation Health Promotion Research Group, Department of Public Health, University of Oxford, and Jose Leal and Ramon Luengo-Fernandez, Health Economics Research Centre, Department of Public Health, University of Oxford. This report can be downloaded from the ESC and EHN websites.

3. De Peretti C, Chin F, Tuppin P, Danchin N. Personnes hospitalisées pour infarctus du myocarde en France: tendances 2002-2008. BEH. 2012;41:459-465.

4. Regitz-Zagrosek V. Therapeutic implications of the gender-specific aspects of cardiovascular disease. Nat Rev Drug Discov 2006;5: 425 -439 .

5. Kleijn de MJ, Schouw van der YT, Verbeek AL, Peeters PH, Banga JD, Graaf van der Y. Endogenous estrogen exposure and cardiovascular mortality risk in post- menopausal women. Am J Epidemiol 2002; 155:339-345.

6. Ossewaarde $\mathrm{ME}$, Bots $\mathrm{ML}$, Verbeek $\mathrm{AL}$, Peeters $\mathrm{PH}$, van der Graaf $\mathrm{Y}$, Grobbee DE, van der Schouw YT. Age at menopause, causespecific mortality and total life expectancy. Epidemiology 2005;16: $556-562$.

7. Mendelsohn ME, Karas RH. The protective effects of estrogen on the cardiovas- cular system. N Engl J Med 1999; 340: 1801- 1811.

8. Orth-Gomer K, Leineweber C. Multiple stressors and coronary disease in women. The Stockholm Female Coronary Risk Study. Biol Psychol. 2005; 69: 57-66.

9. http://www.world-heart federation.org/fileadmin/user_upload/ documents/Fact_sheets /2012/PressBackgrounderApril2012WomenCVD.pdf

10. Merz BN. Women and ischemic heart disease: Paradox and pathophysiology. JACC: Cardiovascular imaging 2011;4: 74-77.

11. Perk J, De Backer G, Gohlke H, Graham I, Reiner Z, Verschuren M, et al. European Guidelines on cardiovascular disease prevention in clinical practice (version 2012). The Fifth Joint Task Force of the European Society of Cardiology and Other Societies on Cardiovascular Disease Prevention in Clinical Practice (constituted by representatives of nine societies and by invited experts). Eur Heart J. 2012 ;33:1635-701

12. Mason PJ. Blood pressure and risk of secondary cardiovascular events in women: The women's antioxidant cardiovascular study (WACS). Circulation. 2004;;109:1623-9

13. Varbo A, Benn M, Tybjærg-Hansen A,. Jørgensen AB, FrikkeSchmidt R,. Nordestgaard BG. Remnant Cholesterol as a Causal Risk Factor for Ischemic Heart Disease. J Am Coll Cardiol. 2013 Jan 29;61(4):427-36

\section{Sažetak}

\section{Kontrola faktora rizika kod žena lečenih primarnom perkutanom intervencijom}

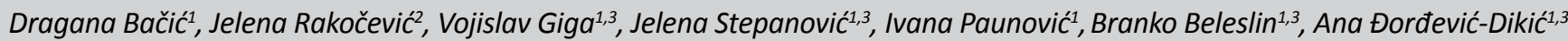
${ }^{1}$ Klinika za kaadiologiju, Klinički centar Srbije; ${ }^{2}$ Institut za histologiju i embriologiju Medicinski fakultet, Univerziteta u Beogradu, ${ }^{3}$ Medicinski fakultet, Univerzitet u Beogradu

Uvod. U prošlosti faktori rizika za KVB kod žena su bili zanemareni jer se smatralo da su žene zaštićene. Takođe, postoje podaci da su faktori rizika kod žena slabo regulisani nakon preležanog infarkta miokarda. Cilj ove studije je da se ispita kontrola faktora rizika kod žena koje su lečene primarnom $\mathrm{PCl}$ nakon preležanog infarkta miokarda.

Metode. Studija uključuje 59 žena (prosek godina $58.53 \pm 8.74$ ) lečenih primarnom PCI nakon IM. Nakon dve godine od događaja kontrola lipida uz optimalni nivo LDL holesterola $<1.8 \mathrm{mmol} / \mathrm{L}$. Definisanje optimalnog nivoa krvnog pritiska $<130 / 80 \mathrm{mmHg}$. Takođe, su ispitani faktori rizika kao što su pušenje i fizička aktivnost (najmanje 30min na dan 5 ili više dana u nedelji), kao i svest o značaju kontrole faktora rizika.

Rezultati. Naši podaci su pokazali da je većina žena imala loše regulisane faktore rizika dve godine od preležanog IM. Povišen krvni pritisak je bio prisutan kod 86\% bolesnica, a LDL holesterol je bio iznad $1.8 \mathrm{mmol} / \mathrm{L}$ u $45 \%$ slučajeva. Više od polovine pacijentkinja (54.2\%) su i dalje pušači. U našoj grupi ispitanica je sedentaran način života bio zastupljen, (52.5\% se nije bavilo fizičkom aktivnošću). Ogromna većina (82.8\%) nije promenila način ishrane i da je taj procenat znatno veći kod žena čiji je BMI>25 nego kod žena čiji je $B M I<25$ ( $p=0.003)$, gde promene u ishrani nisu u korelaciji sa obrazovanjem ( $p=N S$, VSS vs. drugo). Veći deo ispitanica $68 \%$ smatra da ima optimalno regulisane faktore rizika.

Zaključak. Naši podaci pokazuju većina ispitanica ima slabo regulisane faktore rizika nakon preležanog infarkta miokarda. Ključne reči. faktori rizika, žene, perkutane koronarne intervencije 